\title{
Kepribadian dan Kehidupan Hamba Tuhan Menurut 1 Timotius 3:1-13
}

\author{
Bernike Sihombing \\ Sekolah Tinggi Teologi Pelita Bangsa Jakarta
}

\begin{abstract}
The author explains about the characteristic servant of God, a practical discussion with analyzing the 1 Timothy 3:1-13. This text is the key to understand the various aspects characteristic servant of God, in order to have a good character according to the standard of the God
\end{abstract}

Kata Kunci: Character Building: Servant of God

\section{Pendahuluan}

Sebutan hamba Tuhan sangat akrab dikenal dalam dunia kekristenan, gereja apalagi dalam lingkungan pendidikan teologi. Pribadi yang menyandang sebutan tersebut merupakan figur kepercayaan atau perwakilan Allah dalam membina umat-Nya baik secara pribadi maupun secara massal, juga sebagai pengurus harta benda dan rahasia-rahasia yang sangat indah, kaya dan mulia dari kerajaan-Nya itu. Selama Gereja masih ada karakteristik kepribadian kehidupan seorang hamba Tuhan merupakan isu yang selalu hangat dan perlu dibicarakan sebagai koreksi. Profesi seorang Hamba adalah pekerjaan yang baik, istimewa, sakral dan mulia. Arti dari kata "Hamba" seseorang yang bekerja untuk keperluan orang lain (tuannya) atau melaksanakan kehendak tuannya dan sekaligus ia menjadi milik tuannya. ${ }^{1}$

Di dalam Alkitab Perjanjian Lama kata Hamba Tuhan ada dipakai sebanyak 28 kali, dan bahasa Ibraninya dipakai dengan kata 'Ebed Adonay' atau (Inggris: Servant of the Lord) artinya hamba dari Allah yang Maha tinggi pencipta langit dan bumi. ${ }^{2}$ Sedangkan di dalam Perjanjian Baru sebutan hamba Tuhan dipakai dengan kata dou'lo kuvrio (dulos kurios) atau (Inggris: Servant of the God) yang artinya sama dengan istilah dalam bahasa Ibrani seperti

1 . J. W.L. Hoad, “Hamba," dalam Ensiklopedi Alkitab Masa Kini, pen., M. H. Simanungkalit, peny., J. D. Douglas (Jakarta: Yayasan Komunikasi Bina Kasih/OMF, 1996), 2:360.

2 . Jay P. Green, The Interlinear Bible Hebrew Greek English, With Strong's Concordance Numbers Above Earch (London: Hendrikson Publishers, 1985), 198. 
yang telah disebut diatas, dan kata tersebut digunakan hanya ada sebanyak 2 kali saja (Luk. $1: 38 ; 2 \operatorname{Tim} .2: 24){ }^{3}$

J.W.L. Hoad mengatakan bahwa di dalam kehidupan keagamaan orang Israel sebutan hamba Tuhan dipakai untuk menunjukkan pada kerendahan diri seseorang dihadapan Allahnya. (Kel. 4:10, Mzm.119:17, 143:12), juga pemakaian kata tersebut dipakai untuk menyatakan rendahnya kedudukan pembicara, yaitu menyatakan tuntutan ilahi yang mutlak terhadap seorang anggota dari umat yang dipilih-Nya. ${ }^{4}$

Sebutan hamba Tuhan secara umum seperti dalam dunia sekuler maupun gereja dipandang memiliki makna dan nilai yang sama yang mengarah pada pesuruh, wakil Allah yang Maha Tinggi yaitu Yesus Kristus. Kata tersebut di identikkan dengan orang-orang yang rohaniawan atau disebut juga pelayan Tuhan yang terkait dalam kegiatan dengan pelayanan gereja baik secara langsung atau tidak langsung.

Pertama, dewasa ini banyak orang yang telah menerima profesi sebagai hamba Tuhan tetapi ke-khas-annya sebagai orang yang rohani masih simpang siur hingga seringkali sulit membedakan dalam kesehariannya apakah dia seorang hamba Tuhan atau jemaat biasa. Hal itu bisa terjadi dikarenakan masih belum mengerti betul apa arti yang sesungguhnya karakteristik kepribadian kehidupan dan pelayanan seorang hamba Tuhan. ${ }^{5}$

Kedua, besar kemungkinan cendrung seorang hamba Tuhan akan menjadi batu sandungan seperti di dalam Gereja dan sekitarnya akibat kurangnya memahami pentingnya karakteristik kepribadian kehidupan dan pelayanan seorang hamba Tuhan.

Ketiga, belum tersedianya pembahasan sederhana yang mudah dipahami berkenan dengan karakteristik kepribadian kehidupan dan pelayanan seorang hamba Tuhan karena bagi umat Kristini bahwa pelayanan adalah suatu aktifitas yang sangat penting. Pentingnya pelayanan yang telah diteladankan Tuhan Yesus (Mat. 28:19-20), rasul Paulus menekankan keseriusan untuk memiliki karakteristik kepribadian kehidupan dan pelayanan hamba Tuhan. Mustahil memberikan hasil pelayanan yang baik apabila paham karakteristik kepribadian kehidupan dan pelayanan hamba Tuhan ini tidak menjadi prioritas. Dengan demikian karakteristik kepribadian, kehidupan hamba Tuhan merupakan ciri positif yang menandai sikap para hamba Tuhan yang baik.

\footnotetext{
3 . James Strong, Strong's Exhaustive Concordance (Tennessee, Nashville: Crysade Bible Publishers, 1958), 906.

4 . J.W.L.Hoad, "Hamba," 1:360. 2002), 35 .

5 . H. Soekahar, Potret Pendeta di Tengah-tengah Masyarakat Pluralis Modern (Malang: Gandum Mas,
} 
Karakteristik kepribadian kehidupan dan pelayanan seorang hamba Tuhan penting untuk dipelajari, supaya dapat mengetahui dan dapat membedakan pribadi seseorang apakah seseorang itu jemaat biasa atau hamba Tuhan. Pemahaman tersebut dapat juga dipakai untuk mengetahui apakah seseorang itu seorang yang benar-benar menyadari bahwa dirinya menghidupi sebagai seorang hamba Tuhan yang baik atau ia hanya sekedar hamba Allah karena profesi belaka.

Pertanyaan yang muncul adalah, "seberapa pentingkah kesiapan menjadi hamba Tuhan?” dan “apa saja yang menjadi persyaratan jabatan itu?" Paulus tidak menghendaki gereja menyokong seseorang yang melayani sebagai hamba Tuhan yang hanya didasarkan keinginan pribadi, karena punya pendidikan, beban, panggilan atau visi yang diangankan, juga hanya sekedar pengalaman dalam keorganisasian gereja saja. Jangan ada hamba Tuhan dalam pelayanan mencari keuntungan sendiri (1Tim.6:10), menjadikan gereja seperti perusahaan, karena gereja bukanlah perusahaan pribadi atau keluarga, tetapi jemaat Allah yang hidup. Secara keseluruhan bagaimana harus hidup sebagai seorang hamba Tuhan didalam gereja dan sekitarnya. ${ }^{6}$

Seseorang yang terpanggil sebagai hamba Tuhan berarti siap meninggalkan dunia lamanya. Ia harus bertobat, dan menerima Yesus sebagai Tuhan dan Juru selamat pribadinya. Yang baru disebut itu adalah syarat mutlak dan tidak dapat di reduksi, dan pengalaman lahir baru itu penting, karena itu merupakan kebutuhan pokok bagi seorang calon hamba Tuhan (Yoh.3:1-21). Seorang hamba Tuhan haruslah siap memiliki standar moral, kesalehan, kesucian, memiliki pergaulan yang akrab dengan Allah. Dalam pergaulannya dengan jemaat, sekitarnya, ia harus menunjukkan buah-buah Roh yang nyata dalam hidup setiap hari, juga menjadi teladan dalam segala kehidupan.

Rasul Paulus tegas berkata, "Ikutlah teladanku" (Fil.3:17). Seorang hamba Tuhan harus memiliki kehidupan yang benar, diterima oleh masyarakat gereja, ini adalah sebuah integritas diri yang sangat penting dalam menunjang diri sebagai hamba Tuhan. ${ }^{7}$ Hamba Tuhan yang siap masuk dalam pelayanan khususnya bagi yang sudah berkeluarga, Paulus menekankan memiliki pernikahan yang baik, artinya hubungan suami istri ada keharmonisan, juga hubungan dengan anak terjalin dengan baik.

Seperti yang terdapat dalam 1 Timotius 3:1, ada kata kalou' ergou (kalou ergu) diartikan "pekerjaan yang baik." Kata itu menunjuk bahwa predikat seorang hamba Tuhan adalah predikat yang mulia. Dengan demikian seseorang yang menjadi hamba Tuhan

6. C. Groenen, Pengantar Ke dalam Perjanjian Baru (Yogyakarta: Kanasius, 1989), 309.

${ }^{7}$ Ralph M. Riggs, Gembala Sidang Yang Berhasil (Malang: Gandum Mas, 1996), 18. 
memiliki persiapan diri dimulai masuk pada saat seseorang itu merasa terpanggil. Namun menjadi perhatian apakah kata terpanggil itu benar-benar diterima dari Tuhan. Bila benarbenar dari Tuhan, tentu ada pengalaman-pengalaman istimewa dalam hidupnya, paling tidak ada visi dan misi yang ia terima dari Tuhan atau ada sesuatu yang khusus dalam hidupnya, sehingga Tuhan memanggilnya menjadi hamba-Nya.

Beberapa contoh dalam Kitab Perjanjian Lama memberikan bukti-bukti bahwa orang yang terpanggil menjadi hamba Tuhan memiliki pengalaman-pengalaman istimewa atau memiliki keistimewaan dalam hidupnya. Pertama, Abraham, ia terpanggil menjadi hamba Tuhan sejak ia masih tinggal di Ur-Kasdim (Kej.11:31). Pengalaman yang sangat spektakuler dari diri Abraham adalah karena panggilan itu ia harus meninggalkan tanah kelahirannya untuk memenuhi panggilannya masuk ke tanah Kanaan, yang merupakan tanah yang belum ia ketahui secara geografisnya (Kej.12:1-9). Tetapi karena ada keistimewaan dalam diri Abraham yaitu imannya yang begitu besar, hingga tercatat menjadi satu sejarah bahwa Abraham memiliki karakteristik sebagai seorang hamba Tuhan yaitu "bapa orang yang beriman." 2

Kedua, Musa, yang lahir di Mesir dan ayahnya bernama Amran dari suku Lewi (Kel. 6:20) dan ibunya bernama Yakhebed juga dari suku Lewi. Dalam bahasa Ibraninya 'moshe' yang artinya "orang yang diambil dari air." Pengalaman Musa terpanggil menjadi hamba Tuhan yang sangat spektakuler ia rela meninggalkan jati dirinya sebagai orang yang terpandang di Mesir, juga sebagai orang yang memiliki pengaruh dalam pembangunan kota Mesir. Ada sesuatu rencana yang besar diberikan Allah dalam pemanggilannya sebagai hamba Tuhan yaitu untuk membebaskan bangsa pilihan (bangsa Israel) dari tanah Mesir. Yang terpenting tercatat dalam sejarah bahwa karakteristik Musa sebagai hamba Allah adalah perantara Allah memberikan "sepuluh perintah Allah" (Dasa Titah) yang ia terima langsung dari Allah di Gunung Sinai, juga tercatat sebagai pembuat "pentateuk" yaitu lima kitab pertama dari isi Alkitab kitab Kejadian, Keluaran, Imamat dan Ulangan. ${ }^{3}$

Ketiga, Yunus, dalam bahasa Ibraninya disebut 'yona' yang artinya "merpati” di kenal sebagai seorang nabi Allah dan lahir di Gat-Hefer yaitu putra seorang perempuan Sunem yang pernah dihidupkan kembali oleh nabi Elisa dari kematian. ${ }^{4}$ Pemanggilan Yunus yang spektakuler menjadi hamba Tuhan kesaksian hidupnya semasa usia anak-anak itu, dan

2. Al-Qur'an (Milik Departemen Agama RI Proyek Pengadaan Kitab Suci Al-Qur'an), 19 Maryam 41, pen. T. M. Hasbi Ashshiddiql, H. Bustami A. Gani dan lainnya (Jakarta: Bumi Restu, 1971), 467.

3. Mary Hartanti, Biodata Tokoh-tokoh Alkitab Perjanjian Lama Statistik, Ringkasan Kronologis \& Theologis (Jakarta: Markus Agung), 63.

4. Jay Green, The Interlinear Bible Hebrew Greek English, With Strong's Concordance Numbers Above Each Word. (London: Hendrikson Publishers, 1985), 2119. 
riwayatnya selama 3 hari tiga malam dalam perut ikan besar (Yun.1:17). Meski Yunus diketahui sebagai nabi yang keras kepala tetapi ia juga tercatat memiliki karakteristik sebagai hamba Tuhan atas kesadarannya atau pertobatannya sebagai seorang nabi yang menganggap misi penyelamatan kota Niniwe untuk bertobat adalah satu kekeliruan. ${ }^{5}$

Kitab Perjanjian Baru juga memberikan bukti-bukti bahwa orang yang terpanggil menjadi hamba Tuhan memiliki pengalaman-pengalaman istimewa atau yang terpanggil itu memiliki keistimewaan dalam hidupnya seperti berikut di bawah ini.

Pertama, Yohanes pembaptis, putra imam Zakharia dengan Elisabet (Luk. 1:5). Yang menjadi spektakuler dalam panggilan Yohanes pembaptis sebagai hamba Tuhan ketika ia sejak dari dalam kandungan telah ditentukan menjadi hamba Tuhan. Dalam pelayanannya yang sangat dikenal memiliki karakteristik sebagai hamba Tuhan, bahwa ia telah menjadi pembuka jalan bagi kedatangan sang Mesias, dan juga yang mempopulerkan baptisan sebagai tanda pertobatan (Mat. 3:11).

Kedua, rasul Paulus sebagai penulis surat 1 Timotius. Meski sebelumnya Paulus seorang Guru (seorang teolog) yang mengetahui isi Taurat Yahudi, itu bukan menjadi satu alasan bahwa ia seorang hamba Tuhan. Perlu diketahui bahwa yang menjadi pengetahuannya ia telah menerima kebenaran dan menjadi seorang hamba Tuhan disaat pertemuannya langsung dengan Tuhan Yesus di Damsyik. Ketika ia meminta surat kuasa dari majelismajelis Yahudi di Damsyik ketika Paulus masih memakai nama Yahudinya yaitu Saulus, supaya, jika ia menemukan laki-laki atau perempuan yang mengikuti Jalan Tuhan, ia menangkap mereka dan membawa mereka ke Yerusalem untuk dianiaya. Damsyik merupakan ingatan yang sangat spektakuler bagi Paulus dalam persiapannya menjadi hamba Tuhan (Kis. 9:1-19, paralel: Kis. 22:3-16; 26:9-18).

Dengan keistimewaan-keistimewaan yang ada dalam diri Paulus seperti pengalaman pemanggilannya yang pasti juga seorang yang terpelajar) maka ia dikenal memiliki karakteristik sebagai seorang hamba Allah, seperti yang sangat populer ia penulis buku terbanyak dalam Alkitab yang merupakan tulisan yang sangat terlaris dipelajari sepanjang abad.

Jadi, setiap orang yang terpanggil menjadi hamba-Nya tentu ada keistimewaan dalam hidupnya, baik melalui pemanggilan pada awalnya, atau buah yang akan dipersembahkan selama pelayanan sebagai pertanggung-jawaban sebagai seorang Hamba (Band. Mat. 7:16, 20, Luk. 6:44).

\footnotetext{
5. Frank M. Boyd AB, Kitab Nabi-nabi Kecil, (Malang: Gandum Mas, 1999), 28.
} 


\section{Pembahasan}

Profesi sebagai seorang hamba Tuhan profesi yang sakral dan mulia untuk itu sangat dibutuhkan satu komitmen hingga dapat mencapai sasaran. Dalam 1 Timotius 3:2 di awal ayat tersebut ada dituliskan kata "dei`ou^n to;n ejpivskopon ajnepivlhmpton eivai (dei oun ton episkopon anepilhmpton eimai) artinya "oleh karena itu hamba Tuhan haruslah yang tidak bercacat". Seperti yang telah dibahas penekanan frase tidak bercacat bukanlah dimaksud cacat fisik, tetapi menegaskan bahwa setiap yang menjadi hamba Allah mutlak memiliki jati diri yang baik. Konsekuensi dari kemutlakan yang dimaksud dituntut satu komitmen pada panggilan tersebut, dengan demikian siap memenuhi segala aturan-aturan yang merupakan ketentuan-ketentuan dan aturan main sebagai seorang hamba Tuhan. Komitmen masuk dalam pelayanan adalah satu kesungguhan hidup dalam kekudusan (1Pet. 1:6), bukan untuk menyenangkan hati manusia tetapi untuk menyenangkan hati Allah dan itu adalah satu kebenaran yang tidak dapat direduksi. ${ }^{6}$

Mengenai hal komitmen, Lukas juga menuliskan apa yang pernah diucapkan Yesus Kristus dalam suratnya Lukas 9:62, "Setiap orang yang siap untuk membajak tetapi menoleh ke belakang, tidak layak untuk Kerajaan Allah," Ayat tersebut membenarkan bahwa yang ingin menyatakan diri untuk menjadi hamba Tuhan, komitmen sangat dibutuhkan, siap untuk masuk pada apa yang menjadi tuntutan panggilan itu, seperti meninggalkan kebiasaankebiasaan masa lalu atau kepentingan-kepentingan diri.

Mengingat predikat seorang hamba Tuhan adalah predikat yang mulia, dengan demikian seseorang dalam mengabdikan diri sebagai pelayanan yang baik tentu mencapai semaksimal mungkin melakukan persiapan-persiapan agar lebih efektif dalam memberikan yang terbaik, karena pendidikan itu pada hakekatnya adalah proses pendewasaan. ${ }^{7}$ Di bawah ini akan dipaparkan hal tersebut.

Saat ini dapat dikatakan zaman sudah sangat maju, dan bila dibandingkan dengan jaman Perjanjian Lama maupun jaman Perjanjian Baru. Jarak perbedaannya seperti antara langit dan bumi pada tingkat kemajuannya. Pendidikan keagamaan khususnya pendidikan theologia belakangan ini juga begitu banyak telah dibuka atau didirikan, itu menunjukkan betapa pentingnya pendidikan itu. Menjamurnya pendidikan theologia pada dasarnya bukan untuk sekedar hanya menciptakan lapangan kerja bagi guru atau dosen theologia, tetapi

\footnotetext{
6 . Joyce Meyer, Pemimpin Yang Sedang Dibentuk, hal-hal Penting Untuk Menjadi Seorang Pemimpin Yang Berkenan di Hati Allah (Jakarta: Imanuel, 2002), 256.

7. M. Dimyati Mahmud, Psykologi Pendidikan Suatu Pendekatan Terapan (Yogyakarta: BPFEYogyakarta, 1990), 15.
} 
mereka rindu agar pengetahuan tentang Alkitab lebih memadai dan penganalisaannya agar lebih tepat dan benar.

Selayaknya para hamba Tuhan mendapatkan pendidikan yang mapan setidaknya sebagai bandingan pendidikan, sebagaimana Paulus memiliki pendidikan formal. Mengingat jemaat-jemaat gereja saat ini kini rata-rata sudah mengenal pendidikan meski pendidikan sekuler, dan pendidikan itu sudah pada jenjang yang sangat tinggi, artinya untuk bandingan pendidikan. Sangat disayangkan di zaman modern ini bahwa ada sebagian gereja dari kalangan tentu yang membenarkan seseorang diangkat menjadi pejabat gereja (pendeta) yang hanya memiliki pendidikan formal melalui School of Ministry (SOM), sebuah jurusan pendidikan selama tiga bulan. ${ }^{8}$ Hal tersebut seharusnya menjadi pertanyaan mengapa terjadi demikian. Bandingkan dengan pendidikan yang diterima oleh rasul-rasul yaitu murid-murid Yesus, ketika mereka bersama-sama dengan Yesus selama tiga setengah tahun yang dapat disejajarkan pada saat ini adalah tingkat kesarjaan yaitu Strata satu (S1) dan dosen para rasul saat itu langsung dengan Yesus (Maha Guru).

Meski para rasul sudah bersama Yesus tiga setengah tahun, para murid belum diperkenankan untuk pergi menginjil sebelum mereka mendapat pengesahan langsung dari Allah sendiri yaitu pengalaman turunnya Roh Kudus yang dikenal dengan hari Pentakosta. (Pentabisan sebagai rasul siap untuk pergi melanjutkan teladan yang telah di ajarkan oleh Yesus) yang sejajar pada masa kini disebut wisuda. Yang menjadi pertanyaan apakah hamba Tuhan yang tidak pernah mengecap sekolah Theologia selama tiga tahun maka tidak layak disebut sebagai hamba Tuhan atau tidak memiliki karakteristik sebagai seorang hamba Tuhan? Ataukah bagi seorang hamba Tuhan tidak diperlukan pendidikan yang lebih tinggi? Masalahnya bukan sah atau tidak sah, memeliki karakteristik menjadi seorang hamba Tuhan perlu ada satu keterbukaan. Alkitab senantiasa konsisten dan releven pada setiap zaman. Dan perlu diketahui zaman ini bukan lagi zaman istilah "kuda gigit besi."

Mengingat juga, pengalaman-pengalaman yang ada, tingginya pendidikan theologia seseorang mampu menggeser nilai keimanan yang mengarah pada arti otoritas Alkitab, hingga menganut paham bahwa Alkitab bukan lagi seutuhnya sebagai firman Allah. Seperti pengalaman seorang ahli theologia yang bernama Hobbes yang dituliskan oleh Eta Linnemann dalam bukunya, Hobbes mengatakan, "saya yakin bahwa Alkitab tidak dapat memberitahukan wahyu apapun, dan mengenai isi Alkitab banyak hal yang tidak masuk akal. Hobbes juga menambahkan bahwa ilmu pengetahuan merupakan berhala bagi manusia

8. Tata Gereja dan Tata Tertib Gereja Bethel Indonesia, Badan Pekerja Harian Gereja Bethel Indonesia (Jakarta), 15-16. 
modern. ${ }^{9} \quad$ Mungkinkah pengalaman ini membuat beberapa hamba Tuhan memberi kesimpulan singkat bahwa pendidikan theologia tidaklah dominan bagi seorang abdi Allah?

Pentingnya pendidikan bagi hamba Tuhan perlu satu penyadaran dan bukan merupakan pembodohan hingga pengetahuan bagi seorang hamba Tuhan disimpulkan merupakan berhala. Pendidikan bagi seorang hamba Tuhan bukan suatu penyesatan, tetapi pendidikan tersebut lebih sekedar pengajaran mengenai agama Kristen. Selain ilmu itu sendiri, merupakan wadah pemahaman Alkitab seperti untuk pendidikan keluarga, pendidikan penataran pendeta, pendidikan pembinaan warga gereja, pendidikan konsling dan sebagainya. Juga untuk jangkauan anak pendidikan sekolah minggu, pendidikan untuk anak remaja, pendidikan untuk orang dewasa, pendidikan untuk lanjut usia, pendidikan untuk pelayanan, pendidikan untuk ibadah, pendidikan untuk orang tua termasuk untuk pendidikan hubungan suami istri, pendidikan kematian, pendidikan untuk kepemimpinan dan sebagainya. ${ }^{10}$

Yang menjadi pertanyaan seberapa pentingkah pendidikan theologia bagi seorang hamba Tuhan dan sejak kapan dikenal? Di bawah ini akan dipaparkan pendidikan formal dan non formal dalam Alkitab seperti dalam kitab Perjanjian Lama dan kitab Perjanjian Baru sebagai pengetahuan bagaimana peranan pendidikan theologia dalam membina umat-umat Tuhan, dan juga sebagai bukti bahwa pendidikan theologia telah dikenal sejak masa-masa Perjanjian Lama.

\section{Perjanjian Lama}

Sejak masa Perjanjian Lama pendidikan theologia sudah dikenal, meski pada masa Perjanjian Lama acuan sebagai gedung sekolah seperti gedung sekolah pada zaman modern ini tidak ada, tetapi pada zaman itu bait Allah selain dipakai tempat ibadah juga digunakan sebagai gedung tempat belajar mengajar. Istilah bagi orang yang berpendidikan dikenal pada zaman itu dengan sebutan 'limmdin' dan 'talmid' yang artinya pengikut (1Taw. 25:8).

Musa adalah seorang yang terpelajar formal di istana Mesir sebagaimana layaknya seorang pangeran dalam istana Firaun, dan pendidikan non formal theologia ia mendapatkan selama di padang gurun. Dengan pengalaman dan pendidikan yang ia memiliki Allah mempercayakannya untuk mengajar masyarakatnya (Ul. 4:10).

Demikian halnya dengan Yesaya juga orang yang berpendidikan, ia dipercayakan Allah untuk mengajar murid-muridnya (Yes. 8:16). Demikian juga sekembalinya bangsa

${ }^{9}$. Eta Linnemann, Teologi Kontemporer, Ilmu atau Praduga (Malang: Departemen Literatur Yayasan Persatuan Pekabaran Injil Indonesia, 1991), 30-3.

10. Andar Ismail, “Kepemimpinan Dalam Pendidikan Agama Kristen” Bergumul Dalam Pengharapan, peny., Perdinan Suleeman, Adji Agung Sutana, A. Rajendra (Jakarta: BPK Gunung Mulia, 1999), 759. 
Israel dari pembuangan di Babilonia, orang-orang Yahudi menyadari bahwa pendidikan rohani diluar rumah tangga sangat dibutuhkan. Menurut Philo Aleksandria ahli pikir Yahudi mengatakan: Synagoge adalah tempat bagi orang Yahudi untuk ibadah dan belajar Taurat. Tempat pendidikan Synagoge tidak ada bandingnya, cara yang dipakai sangat modern. Guruguru bekerja tanpa gaji, dan yang diajar tidak boleh lebih dari pada 25 murid kalau lebih maka seorang asisten harus dicari, setiap pelajar disuruh aktif melalui bertanya dan guru mendengarkan dan menjawab pertanyaan mereka. ${ }^{11}$

\section{Perjanjian Baru}

Di dalam Perjanjian Baru yang dijadikan menjadi pusat tempat pendidikan bagi orangorang Yahudi adalah Synagoge sama halnya dengan pada masa Perjanjian Lama, dan pengajar-pengajar adalah para ahli Taurat. Di dalam kitab Perjanjian Baru hanya sekali saja terdapat dipakai kata untuk sekolah yaitu dalam Kisah Para Rasul 19:9, dipakai dengan kata "scolh" (skhole) yang artinya "ruang kuliah" yaitu ruang kuliah Tiranus.

Rasul Paulus adalah seorang terpelajar dan ia memiliki pendidikan formal di Yerusalem di sekolah Gamaliel seorang rabi yang tersohor dan juga ia termasuk seorang Farisi yang dikenal sebagai ahli Taurat. Didalam Kisah Para Rasul 22:3 Rasul Paulus dengan jelas mengatakan tentang dirinya adalah seorang terpelajar, "Aku adalah orang Yahudi, lahir di Tarsus di tanah Kilikia, tetapi dibesarkan di kota ini; dididik dengan teliti di bawah pimpinan Gamaliel dalam hukum nenek moyang kita, sehingga aku menjadi seorang yang giat bekerja bagi Allah sama seperti kamu semua pada waktu ini”(Kis. 22:3).

Satu bukti pentingnya pendidikan bagi hamba Tuhan akan lebih efektif dalam pelayannnya. Seperti keistimewaan Paulus sebagai seorang yang terpelajar terlihat dari tulisan- tulisannya yang begitu sistematis. Allah memakai kemampuannya itu dan tentu tidak luput dari arahan Roh Kudus Tulisan-tulisan Pauluslah yang terbanyak di dalam Alkitab, ini salah satu bukti bahwa pendidikan itu sangat berarti untuk seorang hamba Tuhan. Bukan berarti seorang hamba Tuhan yang tidak terpelajar tidak dapat dipakai Allah, tetap dapat dipakai, tetapi perlu satu keterbukaan bahwa hamba Tuhan yang dipakai Allah yang memiliki basic pendidikan yang cukup akan lebih efektif di dalam pelayanannya. ${ }^{12}$

Perlengkapan yang seksama bagi seorang hamba Tuhan untuk semua pekerjaan yang baik meliputi pengetahuan yang lengkap akan kitab suci, tidak dapat disangkali bahwa seorang pendeta perlu mendapat pendidikan, pengalaman-pengalaman rohani yang pokok, dan

\footnotetext{
${ }^{11}$. Ruth Laufer, Pedoman Pelayan Anak (Malang: Yayasan Persekutuan Pekabaran Injil Indonesia, t.t), 192.

${ }^{12}$. Riggs, Gembala, 81
} 
harus mempunyai pengetahuan yang lengkap akan firman Allah. Bibir hamba Tuhan harus memelihara pengetahuan sehingga orang mencari pengajaran dari mulutnya (Mal. 2:7), hamba Tuhan itu harus mendapat pelajaran yang seksama perihal kerajaan Surga supaya dapat mengeluarkan harta yang baru dan yang lama dari perbendaharaannya (Mat. 13:52).

Ralph M. Riggs, menuliskan dalam bukunya betapa pentingnya pendidikan itu bagi seorang hamba Tuhan:

Pada dewasa ini dengan pendidikan yang lebih tinggi dan pengetahuan yang lebih maju, dunia semakin menekankan perlunya pendidikan yang matang sebagai persiapan untuk tugas-tugas dalam hidup ini. Harus diakui bahwa pendidikan yang lebih lengkap memberi kesempatan yang lebih besar untuk melayani. Seorang pekerja Kristen yang tidak berpendidikan biasanya hanya dapat melayani kepada orang-orang yang juga tidak berpendidikan, sedangkan orang yang lebih bernasib baik dan rajin dalam mengejar pendidikan yang lengkap dapat melayani tidak saja orang-orang yang tidak perpendidikan. Latihan yang lebih lama dalam menggunakan pikiran untuk memproleh pengetahuan umum akan memberikan kecekatan dan ketetapan dalam berpikir dan kekuatan pikiran dalam melakukan pelajaran yang umum yang sangat diperlukan sebagai persiapan bagi pelayanan . . Alkitab sendiri merupakan karya sastra yang paling agung didunia dan dapat lebih dihargai dan dapat lebih dikuasai oleh orang-orang yang terlatih dalam belajar berpikir. ${ }^{13}$

Jadi, sesungguhnya pendidikan bagi hamba bukan satu pembodohan, namun pendidikan itu satu pendewasaan dan tidak dapat disangkali, bahwa pendidikan itu sesungguhnya sangat perlu untuk mendukung pelayanan. Dengan pendidikan yang cukup maka pelayanan akan lebih efektif dan dalam pemberitaannya akan lebih terarah dan penganaliasaannya lebih akurat.

\section{Rumah Tangga Hamba Tuhan}

Pentingnya profesi seorang hamba Tuhan tidak dapat dipisahkan hubungannya dengan keluarga (1Tim.3:4). Hamba Tuhan yang mengerti benar apa itu keluarga maka ia dapat menyelami dan memberi solusi-solusi dalam ia menjalankan panggilannya sebagai hamba Tuhan. Contohnya, seperti disaat umat membutuhkan satu pelayanan mungkin pelayan hubungan suami istri yang mengalami diskomunikasi dalam keluarga, pelayanan anak-anak keluarga dan pelayanan-pelayanan yang lainnya.

Keluarga hamba Tuhan juga dapat menjadi satu praktek percontohan karakteristik dalam pelayanan, melalui pengalaman-pengalaman yang ia alami itu dapat menjadi satu pelajaran untuk mengetahui langsung bagaimana kehidupan keluarga. Dan melalui kehidupan hamba Tuhan dengan keluarganya, ia dapat secara tidak langsung memberikan contoh kepada

\footnotetext{
13 . Ibid., 16.
} 
sekitarnya yaitu bagaimana sesungguhnya kehidupan keluarga hamba Tuhan yang baik dan harmonis dan yang berkenan kepada Allah.

Di dalam bahasa Yunani dipakai dengan istilah untuk rumah tangga adalah kata oikos yang artinya "house" sedangkan untuk kata keluarga dipakai dengan kata patriav (patria) dan kata ini dalam Perjanjian Baru muncul ada 3 kali saja. ${ }^{17}$ Keluarga hamba Tuhan merupakan keluarga kelompok gereja kecil yang memiliki mezbah keluarga. Keluarga hamba Tuhan yang tidak memiliki mezbah keluarga berarti keluarga tersebut adalah keluarga yang tidak harmonis dengan Allah. Hamba Tuhan selayaknya memberi contoh kepada anggota keluarganya dan juga bertanggung-jawab pada tiap anggota keluarga.

Keluarga hamba Tuhan juga selayaknya memiliki mezbah keluarga dengan demikian kegiatan itu bukan saja untuk mempererat hubungan keluarga dengan Allah tetapi juga untuk mempererat hubungan rumah tangga dalam hubungan orang tua (suami-istri) dan orang tua dengan anak-anaknya. ${ }^{18}$ Allah menciptakan manusia supaya beribadah kepada-Nya, sesungguhnya keluarga hamba Tuhan tidak akan merasa puas kecuali keluarga itu memiliki hubungan pribadi dengan Allah, oleh karena ada kesatuan keluarga dalam mezbah keluarga, maka keluarga itu akan tetap diteguhkan oleh Allah. Dengan demikian selayaknya keluarga hamba Tuhan menjadi pusat pelayanan rohani sebelum melangkah di dalam pelayanan gereja. $^{19}$

Clyde M. Narramore menuliskan dalam bukunya bahwasanya keluarga yang bergaul dengan Allah akan membawa faedah yang besar bagi hamba Tuhan itu sendiri dan keluarganya, sebab doa Mezbah keluarga adalah nafas rohani dan sumber segala kekuatan. Clyde M. Narramore juga menambahkan bahwa kehidupan keluarga hamba Tuhan tanpa doa seperti kehidupan satu keluarga tanpa atap dan bila ada badai menyerang angin bertiup kencang dan hujan turun mereka tidak mempunyai perlindungan terhadap masalah-masalah dan tekanan hidup. ${ }^{20}$ Jadi keluarga hamba Tuhan sepatutnya memiliki mezbah keluarga karena hal itu bukan hanya mempererat hubungan dengan Allah tetapi mempererat keluarga itu sendiri.

"Seorang kepala keluarga yang baik, disegani dan dihormati oleh anakanaknya."(1Tim. 3:4) Dalam bahasa Indonesia tanggung-jawab adalah keadaan yang wajib menanggung segala sesuatu artinya jika terjadi apa-apa atau sesuatu masalah, maka yang memiliki tanggung jawab itu dapat dituntut, dipersalahkan atau diperkarakan. Istilah lainnya

\footnotetext{
17. Wilson, Wilson's Old Testament, 116.

${ }^{18}$. Kenneth Barney, Rumah Tangga Kristen (Malang: Gandum Mas, 1983), 56.

19 . Clyde M.Narramore, Mengadakan Renungan Keluarga (Bandung: Kalam Hidup, 1982), 7.

${ }^{20}$. Ibid., 3.
} 
untuk tanggung jawab adalah disebut "responsibility" yang artinya suatu system dimana seseorang diminta pertanggung-jawabannya atas kegiatan yang terjadi dibidang tertentu. ${ }^{21}$

Panggilan hamba Tuhan dalam memangku jabatan sebagai yang bertanggung jawab dalam keluarga sangat perlu karena tanggung jawab atas pekerjaan yang dipercayakan sebagai hamba Tuhan bukan berarti melalaikan tanggung jawab sebagai yang bertanggung-jawab dalam keluarga. Di dalam menyalurkan tanggung jawab sebagai hamba Tuhan bukan berarti boleh mengorbankan keluarga (istri dan anak-anaknya) oleh karena itu seorang hamba Tuhan harus bijak mengatur waktu dan tenaga. ${ }^{22}$

Di dalam tanggung jawabnya pada keluarga, hamba Tuhan harus memiliki sistem yang berpadan pada Alkitab. Dalam sistem kepemimpinannya harus mengetahui benar bagaimana dan apa posisi setiap anggota, contohnya apakah dia seorang suami, apakah dia seorang istri atau apakah dia seorang anak. Tanggung jawab setiap keluarga apalagi yang disebut keluarga hamba Tuhan merupakan sesuatu yang mutlak dipertanggung-jawabkan dan otoritas masing-masing tiap anggota tidak seharusnya melihat posisi sebagai anggota apa tiap masing-masing. Perlu satu kesadaran diri dan pengkontrolan diri hingga semua itu dapat berjalan dengan baik sesuai dengan apa yang dihapkan tanpa ada benturan-benturan anggota yang satu dengan anggota keluarga yang lainnya.

Jonathan Trisna membuat satu bagan bagaimana sebaiknya susunan otoritas dalam rumah tangga yang bertanggung jawab, sehingga tatanan atau otoritas tiap-tiap anggota keluarga itu memiliki otoritas masing-masing juga memilki tanggung-jawab yang dapat dipertanggung-jawabkan. ${ }^{24}$

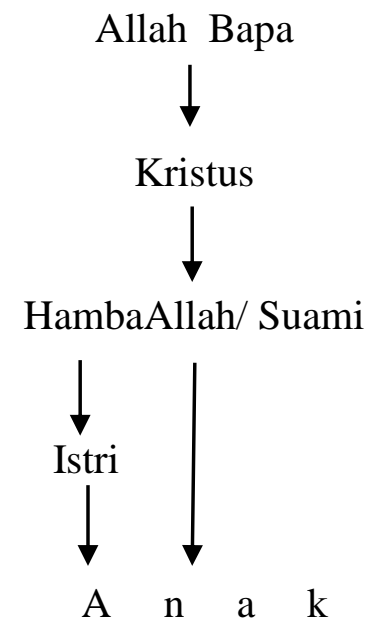

\footnotetext{
${ }^{21}$. Purwadaminta, Kamus, 1139.

${ }^{22}$. J.L.CH.Abineno, Penatua Jabatan dan Pekerjaannya. (Jakarta: BPK Gunung Mulia, 1993), 85.

${ }^{24}$. Jonathan Trisna, Seri Konseling Kristen, Pernikahan Kristen Suatu Usaha dalam Kristus (Jakarta: Institute Theologia dan Keguruan Indonesia, 1994), 39.
} 
Jadi, sebagai hamba Tuhan dalam menjalankan tugasnya tidak ada alasan atau ayat sebagai referensi untuk dapat melalaikan tanggung-jawabnya kepada keluarga sebagai kepala rumah tangga.

\section{Hubungan Orang Tua dengan Anak}

Pemazmur mengatakan bahwa anak adalah milik pusaka pemberian dari TUHAN, (Mzm. 127:3) yang artinya bahwa anak merupakan berkat yang sangat berarti. Allah memberikan ingatan bahwa apa yang telah diterima dari Tuhan hendaklah dijaga dan dirawat sebagaimana seharusnya. ${ }^{25}$

Hamba Tuhan dalam keluarga khususnya dalam menghadapi anak ada kesamaan dengan anak-anak lainnya. (sekuler). Tanggung-jawab seorang hamba Tuhan dalam merawat anaknya merupakan satu keharusan yang harus diperhatikan dengan baik, sebab tanggung jawab itu bukan hanya dalam gereja semata, tetapi juga memberikan kasih sayang dalam keluarga. Seperti yang telah dibahas diatas dalam butir keluarga bahwa anak juga bagian dari keluarga yang memiliki hak yang sama dengan umat untuk mendapatkan bimbingan rohani. Anak-anak hamba Tuhan selayaknya tidak menjadi bantu sandungan dalam pelayanan orang tuanya baik dalam rumah tangga maupun gereja. Sebagai hamba Tuhan selayaknya tidak jemu-jemu mendidik anak-anaknya untuk mengerti bahwa ia adalah anak seorang hamba Tuhan dengan demikian lambat laun anak akan mengerti dunia yang ia hadapi yaitu dunia hamba Tuhan.

Di dalam Perjanjian Lama dituliskan dalam Keluaran 6:7 "haruslah engkau mengajarkannya berulang-ulang kepada anak-anakmu dan membicarakannya apabila engkau duduk di rumahmu, apabila engkau sedang dalam perjalanan, apabila engkau berbaring dan apabila engkau bangun" ini menunjukkan bahwa Allah sagat serius mengingatkan para hamba Tuhan maupun umat-Nya agar anak-anaknya menjadi berkat. Kenakalan anak-anak hamba Tuhan masa kini bukanlah karena terkontaminasi perkembangan zaman, tetapi kenakalan anak hamba Tuhan sejak dari masa Perjanjian Lama sudah ada, tetapi hal itu jangan disalah mengerti, kenakalan anak-anak hamba Tuhan tidak dapat mengubah posisi predikat yang telah ditetapkan Allah dalam hidupnya, sebab bukan karena anak seseorang itu menjadi seorang hamba Tuhan tetapi Allah sendirilah yang menetapkannya.

Di dalam Perjanjian Baru Paulus mencatatkan dalam Efesus 6:1-3, bahwa kewajiban seorang anak untuk menghormati orang tuanya. Dan pada ayat selanjutntya (Ef.

\footnotetext{
${ }^{25}$. Mary Go Setiawani, Pembaharuan Mengajar (Bandung: Kalam Hidup, 1986), 13.
} 
6:4) Paulus mencatatkan bahwa sebagai orang tua tidak sewenang-wenang untuk menyakiti hati anaknya, jadi dalam hubungan itu ada balance (keseimbangan) yang harus masingmasing untuk ditaati.

Jadi kakteristiknya, hubungan hamba Tuhan dengan anak-anaknya seperti mata rantai yang saling mengikat dan memberi tanggung-jawab, tentu hamba Tuhanlah yang menjadi motor sebagai penuntun terhadap tanggung-jawab kerohanian anak-anaknya.

\section{Ishak}

Ishak adalah anak dari nabi Abraham atau yang disebut "bapa orang yang percaya" dan ibunya bernama "Sara" dan setelah melahirkan Ishak pada usia renta yaitu berumur 90 tahun sementara ayahnya Abraham berusia 100 tahun. Ishak artinya "tertawa" (Kej. 21). ${ }^{26}$ Ishak adalah sosok seorang anak yang tiada duanya. Ketika Allah menguji iman Abraham ayahnya, dalam pengujian itu Ayahnya akan mempersembahkannya (atau menyembelihnya sebagai korban bakaran) tetapi Ishak tidaklah memberontak ketika ia diikat dan akan di sembelih. Ishak tahu apa yang dilakukan ayahnya karena ayahnya sangat mengasihi Allah (Kej. 22:9-10).

Dalam penulisan ini Ishak merupakan seorang anak yang perlu diteladani sebagai anak yang mendukung atau sangat mengerti keberadaan ayahnya sebagai Hamba Allah.

\section{Hofni dan Pinehas}

Hofni dan Pinehas yang berdomisili di Syilo dan kedua nama tersebut merupakan anak seorang Imam yang bernama Imam Eli yang menjaga tabut Allah yang disimpan pada Bait Kudus. Hofni dan Pinehas hidup pada masa dimana nabi Samuel masih kecil. ${ }^{27}$ Hofni dan Pinehas anak yang telah membuat malu orang tuanya sebagai Imam. Hofni dan Pinehas melakukan yang sangat Allah tidak sukai, hingga Allah menghukum mereka.

Hofni dan Pinehas adalah anak-anak lelaki Imam Eli adalah yang disebut orang-orang dursila yang tidak mengindahkan TUHAN. (1Sam 2:12). Dosa yang telah mereka lakukan adalah tamak akan makanan, ketika itu setiap kali orang-orang Israel yang ingin memasak persembahan untuk Allah dan masakan itu terlebih dahulu dicipinya semasih dalam kuali (belanga), sedangkan persembahan itu dengan sadar Hofni dan Pinehas mengetahui persembahan makanan yang untuk dipersembahkan kepada Allah. Dalam hal ini Allah melihat bahwa sifat dari Hofni dan Pinehas yang tidak mengindahkan atau memandang rendah korban persembahan untuk Allah (1Sam. 2:17).

\footnotetext{
${ }^{26}$. Haag, Kamus Alkitab, 188.

27 . Ibid., 110.
} 
Kenakalan atau dosa Hofni dan Pinehas yang membuat Allah murka dan yang mempermalukan orang tuanya sebagai Imam bukan hanya karena ketamakannya, tetapi karena ketidaksenonohan Hofni dan Pinehas yang selalu meniduri (menyetubuhi) perempuanperempuan Israel yang melayani di depan pintu kemah pertemuan itu (kemah bait kudus) (1Sam. 2:22). Hofni dan Pinehas adalah dua anak dari hamba Tuhan yang telah mempermalukan ayahnya sebagai hamba Tuhan yaitu Imam Eli dengan demikian kedua anak tersebut tidak layak menjadi percontohan sebagai anak hamba Tuhan.

\section{Adam dan Hawa}

Kisah suami istri yaitu Adam dan Hawa yang merupakan perwakilan keluarga atau hubugan suami istri dari kitab Perjanjian Lama. Sebelum Adam dan hawa jatuh ke dalam dosa, mereka merupakan pasangan suami istri yang berbahagia. Maksud kata bahagia adalah karena hubungan Adam dan Allah masih dekat dengan Allah. Dalam Kejadian 3 diceritakan bahwa karena godaan si ular atau si Iblis maka mereka telah melanggar perintah yang diberikan Allah.

Dosa yang dilakukan oleh Adam adalah memakan buah kehidupan yang tidak boleh disentuh apalagi untuk dimakan yaitu yang ada di taman Eden. Adam sudah tahu kalau istrinya telah melanggar perjanjian dengan Allah yaitu memakan buah kehidupan yang baik dan yang jahat dalam bahasa Arab yang dikenal "buah kouldhi," tetapi karena mengikuti pelanggaran istrinya iapun ikut berdosa dengan ikut memakan buah yang dilarang itu.

Adam bukannya menyadari apa yang telah dilakukan istrinya adalah satu kesalahan besar yang akan berakibat fatal. Kesehatian Adam dan Hawa bersembunyi setelah mereka menyadari mereka telanjang akibat dari dosa itu, Allahpun mengetahui, dan karena pelanggaran itu telah membawa mereka pada kesusahan yaitu jatuh kedalam dosa. Mungkin disaat itu jikalau Adam menyadari apa yang dilakukan istrinya adalah satu dosa, mungkin juga hati Allah masih dapat memaafkannya karena permohonan ampunnya. Yang sering menjadi diskusi dan satu pertanyaan yaitu ketika Allah berseru "Ada . . Adam dimanakah engkau?" Allah maha tahu maha hadir dan maha tahu segalanya tetapi Allah bertanya kepada Adam “Ada ... Adam dimanakah engkau bersembunyi?" Hal ini bukan Allah yang tidak tahu saat itu keberadaan Adam dan Hawa setelah melanggar perintah itu, tetapi Allah memberi kesempatan waktu untuk Adam dan Hawa menyadari akan kesalahan yang telah mereka perbuat. Tunggu dan tunggu ternyata adam dan Hawa bukan menyadari kesalahannya, tetapi 
sibuk dengan membuat cawat untuk menutupi auranya setelah mereka menyadari mereka telanjang. ${ }^{34}$

Adam sebagai suami yang tidak bertanggung jawab yang hanya tahu menyalahkan istrinya yang telah melakukan dosa. Secara hukum yang diberikan Allah kepada manusia, bahwa lelaki itu adalah yang menjadi kepada keluarga yang bertanggung jawab memberi arahan-arahan kepada istri. Artinya Adam seharusnya memberi satu ingatan kepada istrinya bahwa mereka telah berdosa, tetapi Adam tidak melakukan itu, malah itu menyalahkan Allah dengan berkata, "Perempuan yang Kau tempatkan di sisiku, dialah yang memberi buah pohon itu kepadaku, maka kumakan."

Cara Adam tidaklah bijaksana, telah jatuh kedalam dosa bukannya memohon ampun kepada Allah atau menyadari kesalahannya bahwa apa yang telah mereka lakukan adalah satu kesalahan. Dosa Adam dan Hawa dampaknya bukan hanya kepada mereka saja tetapi berdampak pada yang lain. Akibat Dosa Adam dan Hawa seluruh keturunannya menanggungnya atau yang dikenal sebagai dosa warisan. Bila demikian kehidupan suami istri Adam dan Hawa dalam persekongkolannya telah melakukan dosa maka keluarga ini tidak dapat dijadikan satu percontohan.

\section{Penutup}

Hubungan suami istri sebagai hamba Tuhan dibangun dari satu pernikahan antara satu pria Kristen dan satu wanita Kristen dan berdasarkan kepada ketaatan pada Alkitab dan nilai iman juga disertai dengan kasih. $^{28}$ Kehidupan Hamba Tuhan dalam hubungannya sebagai suami istri adalah hubungan yang kudus dalam pernikahannya. Pernikahan itu sejak semula sudah ditetapkan oleh Allah. Adanya pernikahan dan keluarga adalah kehendak Allah sendiri. Allah membuat satu pernikahan dengan berlainan jenis (Laki-laki dan perempuan) agar kedua jenis itu dapat disatukan menjadi satu daging dan untuk saling melengkapi (Kej. 1:27-28).

Keluarga Hamba Tuhan adalah sebuah keluarga unit kecil yang merupakan suatu lembaga yang di dirikan oleh Allah sesuai dengan kepentingannya. Hubungan suami istri hamba Tuhan adalah hubungan yang bersifat kudus dan itu telah Allah tetapkan di taman Eden dan Allah sendirilah yang langsung memberkatinya. ${ }^{29}$

Oleh karena pernikahan yang ditetapkan Allah itu kudus dan tidak boleh dipermainkan dan Allahpun memberi peraturan kepada pernikahan hamba-Nya maupun pernikahan umat-

\footnotetext{
${ }^{34}$. Charles C. Ryrie, Teologi Dasar Panduan Populer Untuk Memahami Kebenaran Alkitab (Yogyakarta: Yayasan Andi, 1992), 1:277.

${ }^{28}$. Larry Christenson, Keluarga Kristen (Bethania: Semarang, 1994), 10.

${ }^{29}$. Wilson Nadeak, Keluarga Lembaga Bahagia (Bandung: Kalam Hidup, 1997), 16.
} 
Nya yang berbunyi sebagai berikut "Hai suami, kasihilah isterimu sebagaimana Kristus telah mengasihi jemaat dan telah menyerahkan diri-Nya baginya (Ef. 5:25).

Kata yang dipakai dalam bahasa Yunani adalah kata ajgapa'te (agapate) yang merupakan kata kerja kini aktif indicatif orang kedua tunggal dari akar kata ajgavph (agape). Melihat dalam ayat tersebut dipakai dalam bentuk aktif artinya hendaklah kasih yang mengarah pada kasih yang terus menerus (online). Kemudian juga bila diperhatikan kata ajgapa te merupakan kata kerja kini aktif indikatif orang kedua jamak berarti penekanannya khusus aktif terus menerus dengan demikian terjemahannya: "hai... engkau suami-suami kasihilah... ") ini merupakan himbauan dan penekanannya dengan sungguh-sungguh agar kasih itu tidak ada kepura-puraan. ${ }^{30}$

Ayat yang sejajar seperti pembahasan di atas terdapat dalam kitab Kolose 3:19 yang berbunyi "hai suami-suami, kasihilah isterimu dan janganlah berlaku kasar terhadap dia." Didalam ayat ini yang menjadi penekanannya adalah dengan kata pikraivnesqe (pikraineste), yang merupakan kata kerja eijmiv (eimi) modus indikatif orang kedua jamak dari akar kata pikrainw (pikrainw) yang artinya "make bitter" (membuat pahit), "embittered" (sakit hati). Jadi bila diterjemahkan Kolose 3:25 adalah "Hai suami-suami, kasihilah isterimu dan janganlah tanamkan kepahitan di hati istrimu."

Peraturan pernikahan hamba Tuhan bukan hanya diberikan kepada hamba-Nya lakilaki tetapi juga untuk pasangan hamba-Nya (istri) dan Allah menetapkan peraturan agar pernikahan itu jangan dipermain-mainkan karena pernikahan itu adalah sesuatu yang serius dan kudus. Allah menetapkan pernikahan itu seperti yang terdapat pada Efesus 5:22, yang mengatakan "hai isteri, tunduklah kepada suamimu seperti kepada Tuhan." Di dalam ayat ini yang menjadi penekanan adalah kata ijdivoi (idiois) merupakan kata sifat dan netral dengan kasus datif, ${ }^{31}$ jamak dari akar kata ijdivo (idios) yang artinya "own" (milik sendiri) diterjemahkan oleh Lembaga Alkitab Indonesia (LAI) dengan "tunduk." Sedangkan King James Version (KJV) menerjemahkan dengan kata "submit" yang artinya "menyerah / kalah." Didalam Alkitab bahasa Indonesia resmi penggunaan kata "idiois" diterjemahkan dengan kata "tunduk" sedangkan New International Version (NIV) menterjemahkan kata idiois (Inggris: own) "milik sendiri, tidak ada tandingannya." Jadi pengartian di dalam Efesus 5:22 adalah, hai, istri-istri, kata "wife” dengan posisi jamak/singular ini berarti dapat ditujukan kepada

${ }^{30}$. Taylor, The Analytical, 3.

${ }^{31}$. Ibid., 16-17. Datif disebut dengan kasus kepentingan. Fungsi terpentingnya adalah digunakan untuk menyatakan obyek tidak langsung (penyerta). Datif juga sering digunakan untuk menyatakan dua konsep yaitu yang pertama menyatakan untuk tempat atau posisi terjadinya tindakan yang dinayatakan verba kalimat. Kemudian yang kedua untuk menjelaskan alat atau sarana yang digunakan untuk pelaksanaan tindakan. 
sang istri maupun ditujukan kepada para istri yaitu mereka-mereka yang telah memiliki suami tanpa terkecuali apakah itu istri hamba Tuhan ataupun istri dari jemaat, tunduklah kepada suamimu atau sesungguhnya suamimu itu dirimu sendiri, atau suamimu milikmu yang tiada tandingannya."

Lary Christenson memberi tanggapan kepada Efesus 5:22 dan mengatakan bahwa kata tunduk yang dimaksud dalam ayat tersebut adalah yang berarti merendahkan hati dan penuh pengertian, mematuhi suatu kuasa atau seseorang yang berwenang yang telah ditetapkan Allah dalam hal ini adalah suami. Kemudian R. P. Matin juga menyatakan bahwa yang dimaksud kata tunduk dalam Efesus 5:22 karena yang melatar belakanginya adalah ibadah, bahwa pelayanan istri terhadap suami di dalam keluarga sesungguhnya adalah merupakan bagian dari pada ibadah. ${ }^{32}$

Seperti yang telah dibahas diatas bahwa hubungan suami istri adalah hubungan yang diikat oleh pernikahan yang sifatnya kudus dan sangat serius dengan itu maka perlu diperhatikan agar pernikahan itu tetap berjalan sesuai peraturan-peraturan yang telah ditetapkan Allah. ${ }^{33}$

Jadi, dari penjelasan peraturan yang telah dibahas diatas yaitu dimana Allah memberikan satu ketetapan kepada hamba Tuhan maupun kepada istri hamba Tuhan bahkan juga peraturan itu berlaku kepada umat-Nya. Hubungan suami istri itu diikat dengan satu pernikahan yang sifatnya kudus. Maka karakteristiknya bahwa suami istri mempunyai hubungan yang sangat erat (pernikahan juga peranannya masing-masing dengan saling mengasihi saling menghargai dan saling melindungi, sesuai peraturan-peraturan yang telah ditentukan Allah dan memiliki hanya satu pasangan hal itu tidak dapat ditawar-tawar.

\section{Referensi}

AB, Frank M. Boyd. Kitab Nabi-nabi Kecil, Malang: Gandum Mas, 1999

Abineno, J.L.CH. Penatua Jabatan dan Pekerjaannya. Jakarta: BPK Gunung Mulia, James Strong, 1993

Agung, Markus. Biodata Tokoh-tokoh Alkitab Perjanjian Lama Statistik, Ringkasan Kronologis \& Theologis Jakarta

Al-Qur'an (Milik Departemen Agama RI Proyek Pengadaan Kitab Suci Al-Qur'an), 19 Maryam 41, pen. T. M. Hasbi Ashshiddiql, H. Bustami A. Gani dan lainnya Jakarta: Bumi Restu, 1971

Barney, Kenneth. Rumah Tangga Kristen Malang: Gandum Mas, 1983

Christenson, Larry. Keluarga Kristen Bethania: Semarang, 1994

C. Groenen, Pengantar Ke dalam Perjanjian Baru Yogyakarta: Kanasius, 1989

${ }^{32}$. R. P. Martin, dalam Tafsiran Alkitab Masa Kini, pen., Broto Semedi, peny., Donald Guthrie (Jakarta: Yayasan Komunikasi Bina Kasih/OMF, 2001), 3:603.

33. M. Sihombing, Bernike Sihombing, Agenda., 8-11. 
Green, Jay. The Interlinear Bible Hebrew Greek English, With Strong's Concordance Numbers Above Each Word, London: Hendrikson Publishers, 1985

. The Interlinear Bible Hebrew Greek English, With Strong's Concordance Numbers Above Earch London: Hendrikson Publishers, 1985

Hoad, J. W.L. "Hamba," dalam Ensiklopedi Alkitab Masa Kini, pen, M. H. Simanungkalit, peny., J. D. Douglas Jakarta: Yayasan Komunikasi Bina Kasih/OMF, 1996

Ismail, Andar. "Kepemimpinan Dalam Pendidikan Agama Kristen" Bergumul Dalam Pengharapan, peny., Perdinan Suleeman, Adji Agung Sutana, A. Rajendra Jakarta: BPK Gunung Mulia, 1999

Laufer, Ruth. Pedoman Pelayan Anak, Malang: Yayasan Persekutuan Pekabaran Injil Indonesia, t.t., 1992

Linnemann, Eta. Teologi Kontemporer, Ilmu atau Praduga Malang: Departemen Literatur Yayasan Persatuan Pekabaran Injil Indonesia, 1991

Mahmud, M. Dimyati. Psykologi Pendidikan Suatu Pendekatan Terapan, Yogyakarta: BPFEYogyakarta, 1990

Martin, R. P. dalam Tafsiran Alkitab Masa Kini, pen., Broto Semedi, peny., Donald Guthrie (Jakarta: Yayasan Komunikasi Bina Kasih/OMF, 2001

Meyer, Joyce. Pemimpin Yang Sedang Dibentuk, hal-hal Penting Untuk Menjadi Seorang Pemimpin Yang Berkenan di Hati Allah Jakarta: Imanuel, 2002

Nadeak, Wilson. Keluarga Lembaga Bahagia Bandung: Kalam Hidup, 1997

Narramore, Clyde M. Mengadakan Renungan Keluarga Bandung: Kalam Hidup, 1982

Riggs, Ralph M. Gembala Sidang Yang Berhasil (Malang: Gandum Mas,1996

Ryrie, Charles C. Teologi Dasar Panduan Populer Untuk Memahami Kebenaran Alkitab Yogyakarta: Yayasan Andi, 1992

Setiawani, Mary Go. Pembaharuan Mengajar Bandung: Kalam Hidup, Mary Hartanti, 1986

Soekahar, H. Potret Pendeta di Tengah-tengah Masyarakat Pluralis Modern Malang: Gandum Mas2002

Strong's Exhaustive Concordance Tennessee, Nashville: Crysade Bible Publishers, 1958

Trisna, Jonathan. Seri Konseling Kristen, Pernikahan Kristen Suatu Usaha dalam Kristus (Jakarta: Institute Theologia dan Keguruan Indonesia, 1994. 